\title{
A comparison of the vegetation of forested and non-forested solution dolines in Hungary: a preliminary study
}

\author{
Zoltán BÁtori ${ }^{1 *}$, Tünde FARKAS ${ }^{2}$, László ERdős ${ }^{1}$, Csaba TöLGYEsI ${ }^{1}$, László KöRMöczI ${ }^{1}$ \& \\ András VoJTKó ${ }^{3}$ \\ ${ }^{1}$ University of Szeged, Department of Ecology, H-6726 Szeged, Közép fasor 52, Hungary; e-mail: zbatory@gmail.com \\ ${ }^{2}$ Directorate of the Aggtelek National Park, H-3758 Jósvafó, Tengerszem oldal 1, Hungary \\ ${ }^{3}$ Eszterházy Károly College, Department of Botany, H-3300 Eger, Leányka utca 6, Hungary
}

\begin{abstract}
The present study compares the vegetation characteristics of two large forested and one large non-forested solution dolines in Hungary. We investigated the species composition and vegetation pattern along north to south transects (across the doline bottoms) and compared the richness of different species groups (dry and wet groups) on the doline slopes. We applied linear regression models for each slope to explore the effects of topography on species richness, and Detrended Correspondence Analysis (DCA) to detect the major gradients of floristic variation within each site. We found that the vegetation changed significantly along all transects; and, regardless of the vegetation cover, the doline bottoms contained several cool-adapted species. Variations within the two species groups were more pronounced on the south-facing slopes. The changes were similar in the forested dolines, indicating the role of forest cover in maintaining many cool-adapted species on the north-facing slopes as well. However, the number of cool-adapted species increased significantly along both slopes of the non-forested doline from the upper edge to the bottom. Contrary to our expectations, the species turnover along the slopes of the non-forested doline was lower than that along the slopes of the forested ones. We conclude that both the forested and non-forested dolines serve as refuges for many plant species adapted to different environmental conditions. Apart from providing an understanding of population patterns along environmental gradients, our results may also contribute to our understanding of an even more fundamental question for a future research agenda: the probable effects of climate change on vegetation characteristics in climatic islands with environmental conditions substantially different from the surrounding areas.
\end{abstract}

Key words: climate change; karst surface; refugium; relict species; species turnover

\section{Introduction}

Karst dolines, i.e., small to large depressions, are among the most interesting objects of karst surfaces. Since their total area may be relatively large in karst landscapes, they influence ecological processes considerably.

As isolated or semi-isolated cool and humid enclaves, dolines are very important from a nature conservation point of view. It has been shown that such depressions are refugia for a variety of species (Beck v. Mannagetta 1906; Horvat 1953; Vilisics et al. 2011). As our previous studies revealed (Bátori et al. 2012; 2014a), the role of the large and deep forested solution dolines of Hungary in plant species preservation is especially important. These studies also establish that the slope of species-area curves of dolines may change markedly depending on which species group is under consideration. For example, the slope of species-area curve is relatively low in the case of widespread species, which occur all over on the karst surfaces, and tends to be steeper if cool-adapted species are considered only. The literature contains many excellent examples where dolines are mentioned as key habitats for rare and endangered plant species (e.g., endemic, mountain, high mountain, marsh, relict and wet-woodland species) (Egli 1991; Vojtkó 1994; Yannitsaros et al. 1996; Dakskobler et al. 2008; Bátori et al. 2009; Lazarević et al. 2009). The most important species belong to the group of climatic relicts (e.g., Dracocephalum ruyschiana or Stachys alpina in Hungary) (Bartha 1933; Bátori et al. 2012), whose populations persist in isolated or semiisolated enclaves of suitable climate space surrounded by areas where the climate is not suitable for them (Hampe \& Jump 2011). The microclimate of dolines represents steep gradients (Gargano et al. 2010; Bátori et al. 2011), which has a profound influence on vegetation composition and results in a great diversity within short distances (Özkan et. al 2010). Temperature inversion and increased soil moisture lead to an inversion of vegetation zones (e.g., mesic beech forests replace dry oak forests on the deeper slopes of dolines) or to the development of edaphic vegetation types (e.g. scree and

\footnotetext{
* Corresponding author
} 


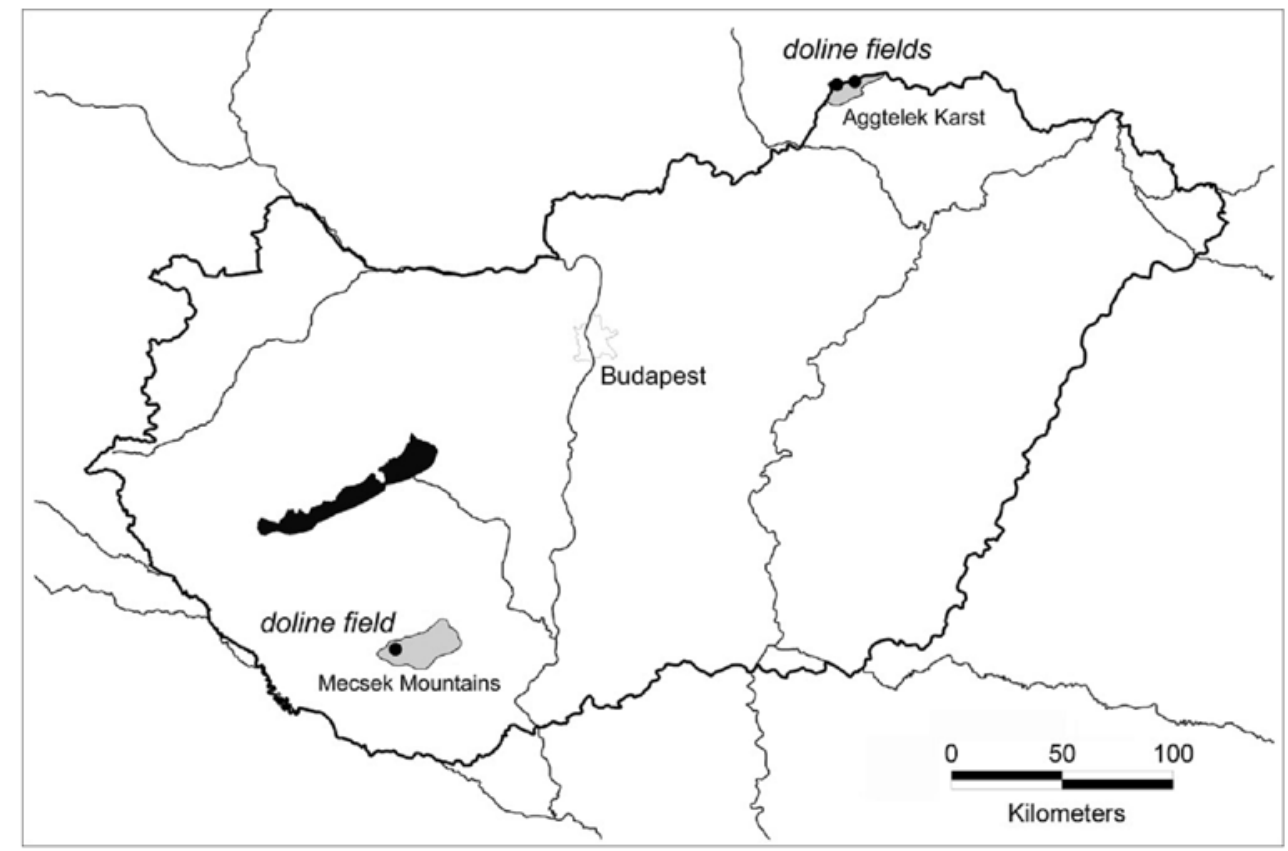

Fig. 1. Location of the study sites in Hungary.

ravine forests) (Horvat 1953; Vojtkó 2003; Bátori et al. 2014a). Sometimes dolines serve as refuges for endemic associations as well (Redžić et al 2011).

As the above-mentioned examples suggest, understanding the interactions among microclimate, topography and vegetation is the key to protecting the biodiversity of dolines and their surroundings. There is no doubt that the strength of temperature inversion, which is influenced predominantly by the topography, has a great impact on plant survival. However, vegetation cover can also have its share in influencing the temporal and spatial variability of temperature in dolines, mainly by modulating the intensity of solar insolation on doline slope surfaces. As previous studies have shown, microclimatic values are usually less extreme in forested dolines than in dolines covered with herbaceous or shrubby vegetation (Bacsó \& Zólyomi 1934; Lehmann 1970). Nevertheless, the spring and autumn temperature variability and extremes in forested dolines may have a significant impact on the preservation and recolonization of cool-adapted species.

In this article, we present and discuss data demonstrating that in the studied forested and non-forested solution dolines many vegetation characteristics show spatial patterns that are interrelated, and such interrelationships contribute to species preservation following local topography. Moreover, we aimed to assess whether forest cover would suppress changes in vegetation characteristics along doline slopes.

\section{Material and methods}

\section{Study sites}

The fieldwork was carried out during the summer of 2007, 2012 and 2013 in three large and deep solution dolines, which can be considered typical for the karst areas of Hungary between 300 and $500 \mathrm{~m}$ a.s.l.

One forested doline (doline 1) was selected in the Mecsek Mountains (southern Hungary) and one non-forested (doline 2) and one forested doline (doline 3) in the Aggtelek Karst region (northern Hungary) (Figs 1, 2). Large and deep non-forested dolines are absent in the Mecsek Mountains.

All dolines had a similar topography (diameter is between $120 \mathrm{~m}$ and $150 \mathrm{~m}$ and depth is between $15 \mathrm{~m}$ and $20 \mathrm{~m})$.

The average annual precipitation of the Mecsek Mountains, where doline 1 is located, is about $700 \mathrm{~mm}$. Due to the sub-Mediterranean climate, the annual maximum values occur during the summer and autumn months. The annual mean temperature is about $9.5^{\circ} \mathrm{C}$ (Marosi \& Somogyi 1990). This doline is situated in the oak-hornbeam belt of the mountain range, in the mosaics of Illyrian type oak-hornbeam (Asperulo taurinae-Carpinetum) and beech forests (Helleboro odori-Fagetum).

The average annual precipitation of the Aggtelek Karst region is about $650 \mathrm{~mm}$ with the annual maximum during summer months. Annual mean temperature is about $9.1^{\circ} \mathrm{C}$ (Ujvárosy 1998). Due to the continental climate, winters are colder than in the Mecsek Mountains. Doline 2 is surrounded by semi-dry grasslands (Polygalo majoriBrachypodietum pinnati) and doline 3 by Central European type oak-hornbeam forests (Carici pilosae-Carpinetum).

\section{Vegetation sampling}

Transects for sampling the herb layer were established across the dolines in north to south direction, traversing their deepest points. Each transect consisted of a series of $1 \mathrm{~m} \times 1 \mathrm{~m}$ plots spaced at $5 \mathrm{~m}$ intervals. At all sites, we recorded presence/absence data of herbaceous plants and tree saplings in each square meter. A total of 86 plots were recorded.

Plant community names were used according to Borhidi et al. (2012), while the names of plant species followed Király (2009). Red-listed plants were identified according to Király (2007). 

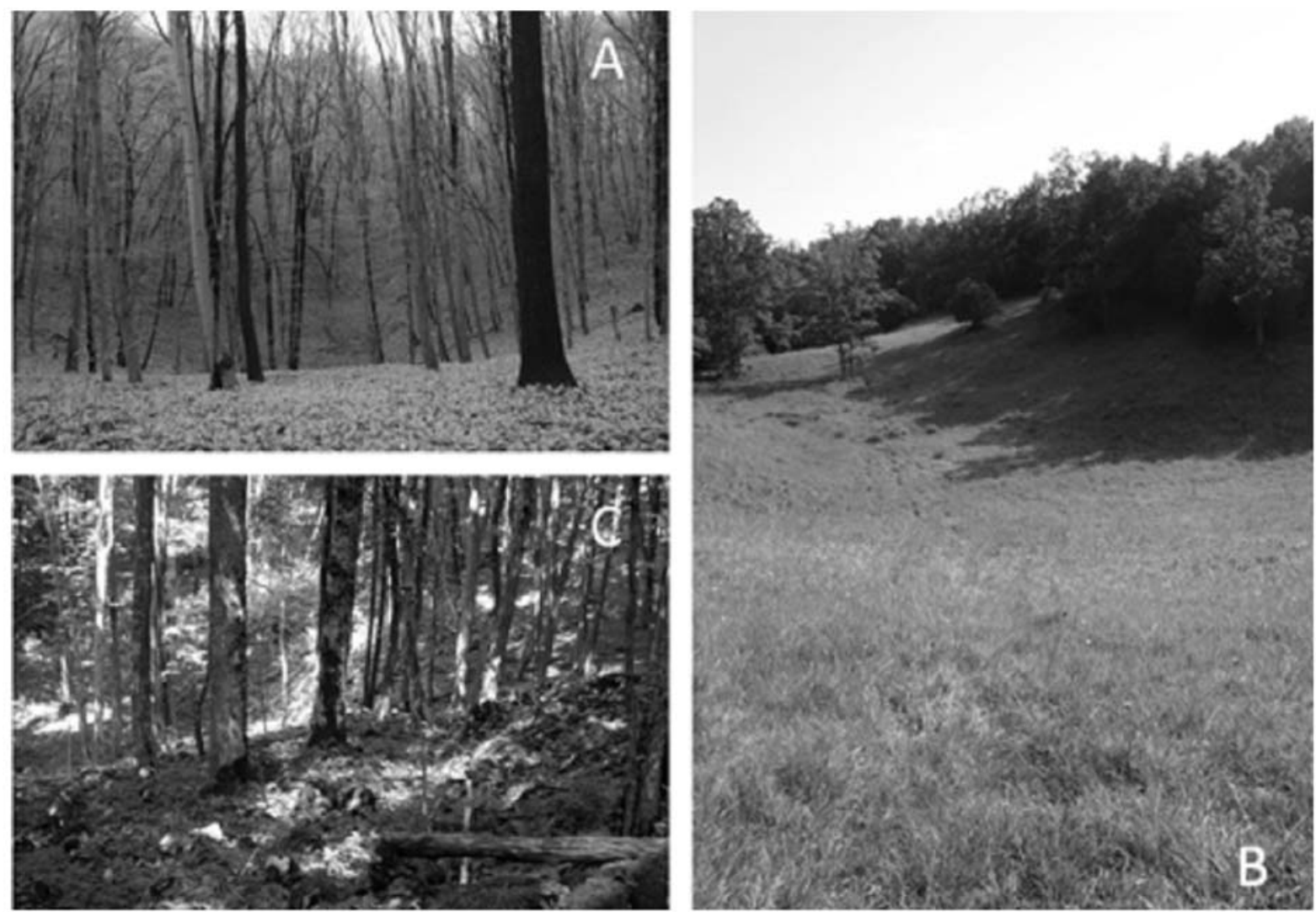

Fig. 2. An oak-hornbeam forest (Asperulo taurinae-Carpinetum) on the rim of doline 1 (A); a semi-dry grassland (Polygalo majoriBrachypodietum pinnati) and a montane hay meadow (Anthyllido-Festucetum rubrae) in doline 2 (B); a scree forest (MercurialiTilietum) in doline $3(\mathrm{C})$. Photos by Tünde Farkas and Zoltán Bátori.

\section{Species grouping}

All vascular plant species recorded along the transects were classified according to their coenological preferences using the classification of Soó (1980) and field observations. Two groups of species were established for each doline. The first group (hereafter called 'dry group') contains species which are associated with drier soil conditions and warmer climate (Quercion farnetto, Quercetea pubescentis-petraeae and Querco-Fagetea in doline 1; CirsioBrachypodion, Festucetalia valesiacae, Festucion rupicolae, Festuco-Brometea and Quercetea pubescentis-petraeae in doline 2; Quercetea pubescentis-petraeae and QuercoFagetea in doline 3) and the second group (hereafter called 'wet group') contains species characteristic of moister soil conditions and cooler climate (i.e., cool-adapted species) (Alnetea glutinosae, Atropion bella-donnae, Calystegion sepium, Fagetalia sylvaticae, Fagion illyricum and TilioAcerion in doline 1; Arrhenatheretea, Fagetalia sylvaticae, Molinio-Arrhenatheretea, Molinio-Juncetea, Nardetalia, Nardo-Callunetea, Pino-Quercetalia, Querco-Fagetea and Tilio-Acerion in doline 2; Galio-Alliarion and Fagetalia sylvaticae in doline 3 ).

\section{Statistical analyses}

Linear regression analysis was used to evaluate the species richness-slope position relationships for both the dry and wet groups along each doline slope. The significance level was chosen $P<0.05$. One-way ANOVA and subsequent Tukey's HSD post hoc tests were applied in order to reveal the differences in species richness between the sites.

Boundary delineation along the transects was done using the moving split-window (MSW) technique (Webster
1978; Bátori et al. 2014a) and field observations.

Detrended Correspondence Analysis (DCA) was used to detect the major gradients of floristic variation of the plots within the study sites (Hill \& Gauch 1980).

Calculations were performed using Past 2.15 (Hammer et al. 2001). The MSW-computations were performed using the statistical language R 2.10.1 (R Development Core Team 2009).

\section{Results}

We detected 40, 128, and 43 species along the transects in doline 1, doline 2 and doline 3, respectively (Figs 3$5)$. Species compositions changed markedly along the transects. Some species occured in every part of the dolines (e.g., Fraxinus excelsior, Hedera helix and Viola reichenbachiana in doline 1 ; Cirsium pannonicum, Festuca rupicola and Salvia pratensis in doline 2; Fraxinus excelsior, Galium odoratum and Viola reichenbachiana in doline 3 ), while others were restricted to only the south-facing slopes (e.g., Carpinus betulus, Carex flacca and Dactylis polygama in doline 1; Chamaecytisus albus, Pulsatilla grandis and Sanguisorba minor in doline 2; Acer campestre, Carex montana and Crataegus monogyna in doline 3), to the north-facing slopes (e.g., Euonymus europaeus; Lathyrus venetus and Mercurialis perennis in doline 1; Convallaria majalis, Galium schultesii and Gentiana cruciata in doline 2; Daphne mezereum, Dryopteris filix-mas and Fagus sylvatica in 


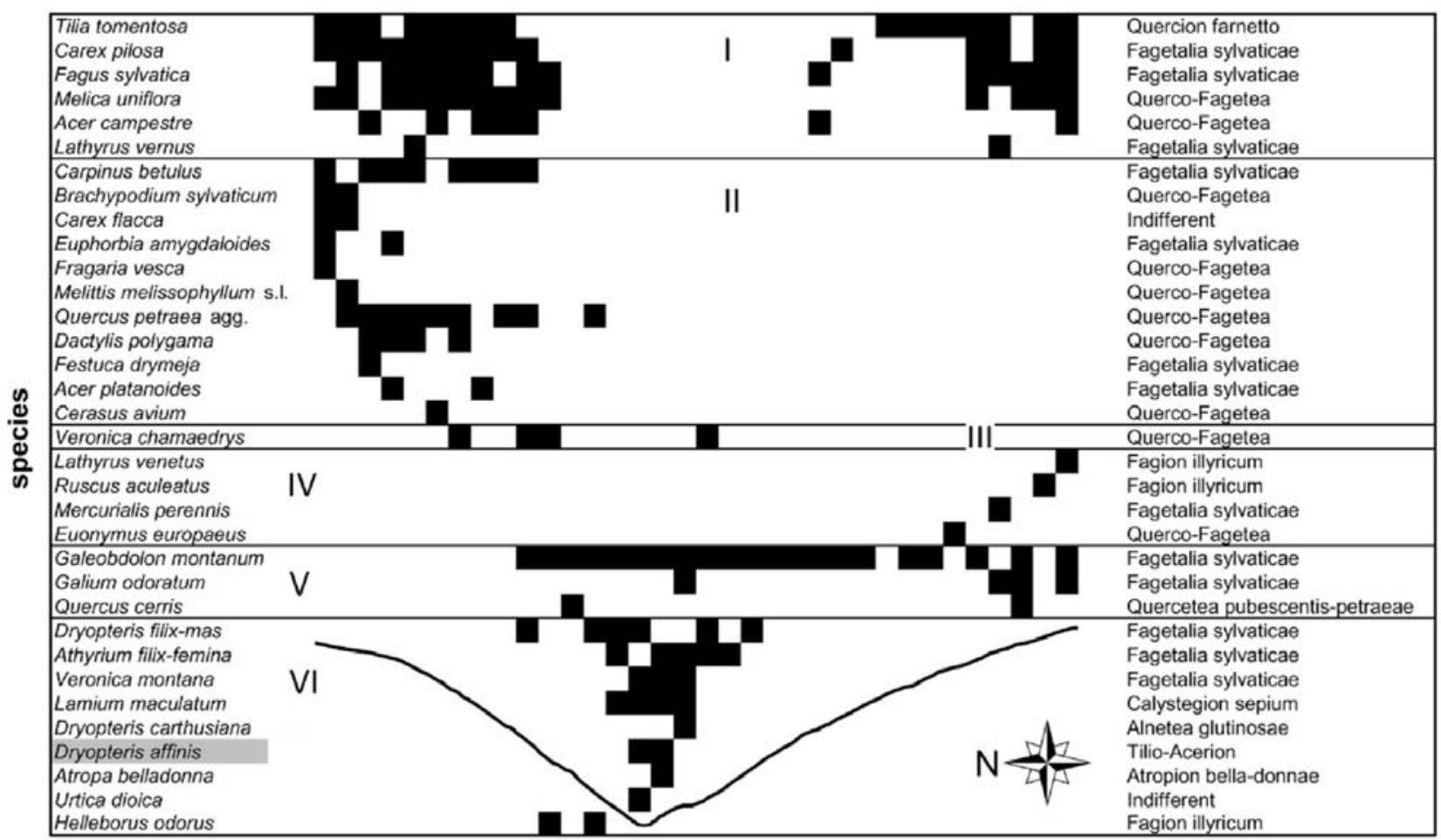

position along the transect

Fig. 3. Species occurrences and relief profile along the transect of doline 1. I - species of the rims and upper slopes; II - species of the south-facing slope; III - species of the south-facing slope and doline bottom; IV - species of the north-facing slope; V - species of the north-facing slope and doline bottom; VI - species of the doline bottom. Those species that occur in every part (I-VI) of the doline transect include Ruscus hypoglossum (Fagion illyricum), Acer pseudoplatanus, Hedera helix, Rubus hirtus agg., Viola reichenbachiana (Fagetalia sylvaticae) and Fraxinus excelsior (Querco-Fagetea). The name of the red-listed plant is grey-shaded.

doline 3) or to the doline bottoms (e.g., Dryopteris affinis, Urtica dioica and Veronica montana in doline 1; Agrostis capillaris, Alchemilla monticola and Botrychium lunaria in doline 2; Paris quadrifolia, Urtica dioica and Stellaria media in doline 3). Most of the red-listed plants (e.g., Astrantia major, Daphne mezereum and Gentianella austriaca) were found on the north-facing slopes or in the doline bottoms. Some of them (e.g., Rubus saxatilis) are very rare in Hungary. The proportion of the red-listed plants was the highest $(8.6 \%)$ in doline 2 .

The species richness of the dry group decreased toward the doline bottom both on the south-facing and the north-facing slopes of doline 1 and doline 3 , and on the south-facing slope of doline 2 , while the species richness of the wet group showed the reverse distribution on both slopes of doline 2 (Fig. 6). However, in the case of the wet group of doline 1 and doline 3 , significant correlation could only be detected along the south-facing slopes.

However, if we consider only the individual coenological groups, for example Fagetalia sylvaticae, we can expect a more precise pattern of species occurrences and related ecological processes (Figs 3-5). QuercoFagetea species were frequent on the rims and southfacing slopes of doline 1 and doline 3, while Fagetalia sylvaticae species dominated (i.e., their proportion was higher) mainly the lower slopes and doline bottoms. Ravine forest species (Tilio-Acerion), wet wood- land species (Alnetea glutinosae) and natural weed species (Atropion bella-donnae, Calystegion sepium and Galio-Alliarion) occurred only on the doline bottoms. More coenological groups could be distinguished in doline 2. Dry grassland species (Festucetalia valesiacae and Festuco-Brometea) dominated the rims and the south-facing slope, hay meadow species (MolinioArrhenatheretea) and mesic forest species (QuercoFagetea) the north-facing slope, while ravine forest species (Tilio-Acerion) and species of nutrient-poor habitats (Nardetalia and Nardo-Callunetea) occured only in the doline bottom.

Doline 2 proved to be much richer in species $(P<0.001)$ than doline 1 and doline 3 , which, in turn, showed no significant difference $(P=0.915)$ regarding species richness (Fig. 7). The DCA ordinations of the samples show a strong gradient along axis 1 with a high species turnover in doline 1 (eigenvalue: 0.63, gradient length: 4.4 S.D. units) and in doline 3 (eigenvalue: 0.65, gradient length: 5.2 S.D. units) and lower species turnover along the slopes of doline 2 (eigenvalue: 0.42 , gradient length: 3.1 S.D. units) (Figs 8-10).

More than one vegetation type was detected along all transects. On the north-facing rim of doline 1 a transitional forest stand occurred, composed of elements of turkey oak-sessile oak forests (Potentillo micranthae-Quercetum dalechampii) and oakhornbeam forests (Asperulo taurinae-Carpinetum). The south-facing and north-facing slopes of the same do- 


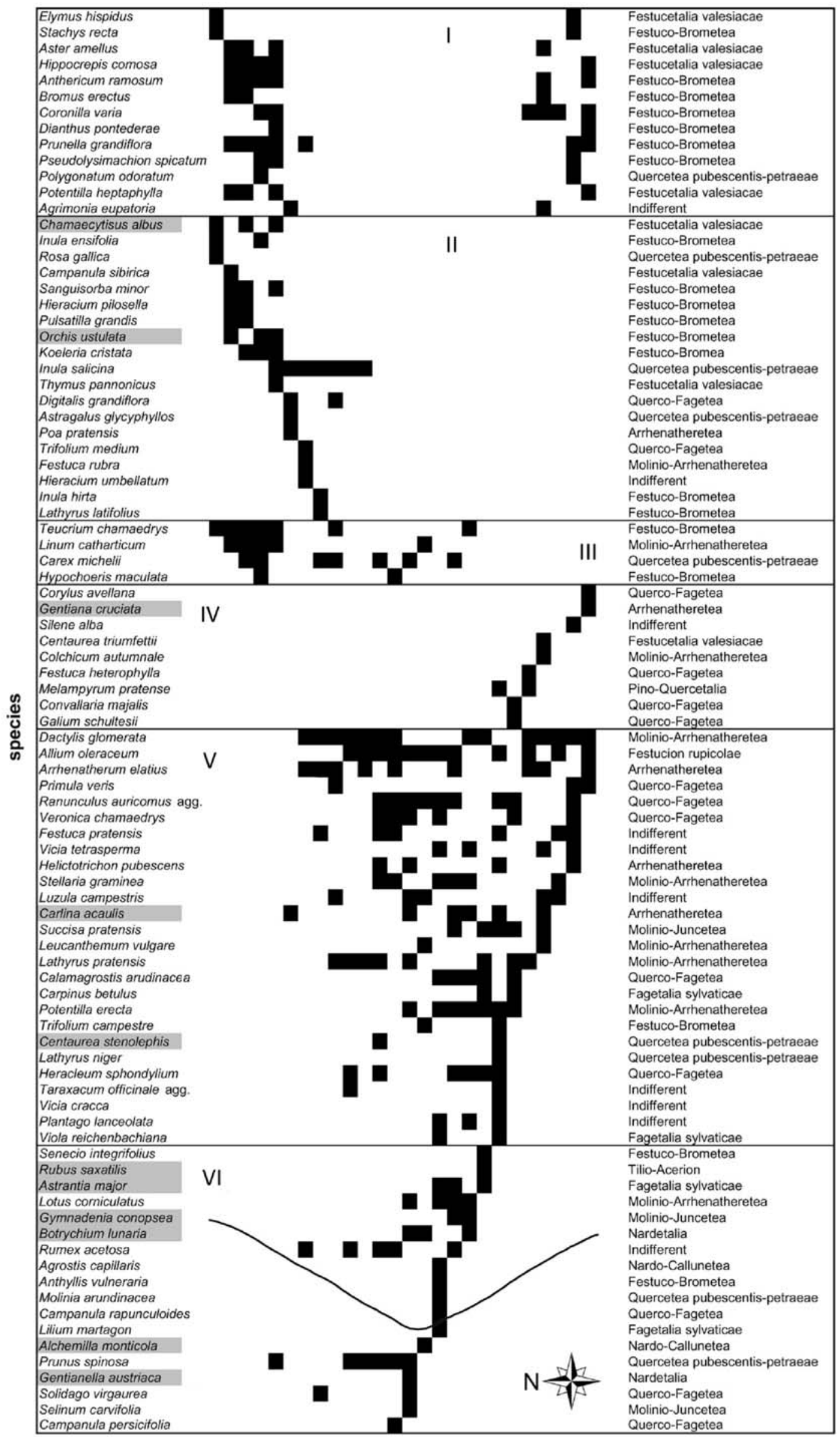


Fig. 4. Species occurrences and relief profile along the transect of doline 2. I - species of the rims and upper slopes; II - species of the south-facing slope; III - species of the south-facing slope and doline bottom; IV - species of the north-facing slope; V - species of the north-facing slope and doline bottom; VI - species of the doline bottom. Those species that occur in every part (I-VI) of the doline transect include Briza media (Arrhenatheretea), Cirsium pannonicum (Cirsio-Brachypodion), Fragaria viridis, Polygala major, Trifolium alpestre (Festucetalia valesiacae), Asperula cynanchica, Brachypodium pinnatum, Euphorbia cyparissias, Festuca rupicola, Filipendula vulgaris, Geranium sanguineum, Helianthemum ovatum, Helictotrichon adsurgens, Phleum phleoides, Plantago media, Ranunculus polyanthemos, Salvia pratensis, Seseli annuum, Thesium linophyllon, Trifolium montanum, Trinia glauca (FestucoBrometea), Achillea collina, Galium verum, Hypericum perforatum, Knautia arvensis, Leontodon hispidus, Pimpinella saxifraga (Indifferent), Serratula tinctoria (Molinio-Juncetea), Cruciata glabra, Symphytum tuberosum, Tanacetum corymbosum (Querco-Fagetea) and Betonica officinalis, Carex montana, Genista tinctoria, Peucedanum cervaria, Potentilla alba, Pulmonaria mollissima, Trifolium pannonicum, Viola hirta (Quercetea pubescentis-petraeae). The names of the red-listed plants are grey-shaded.

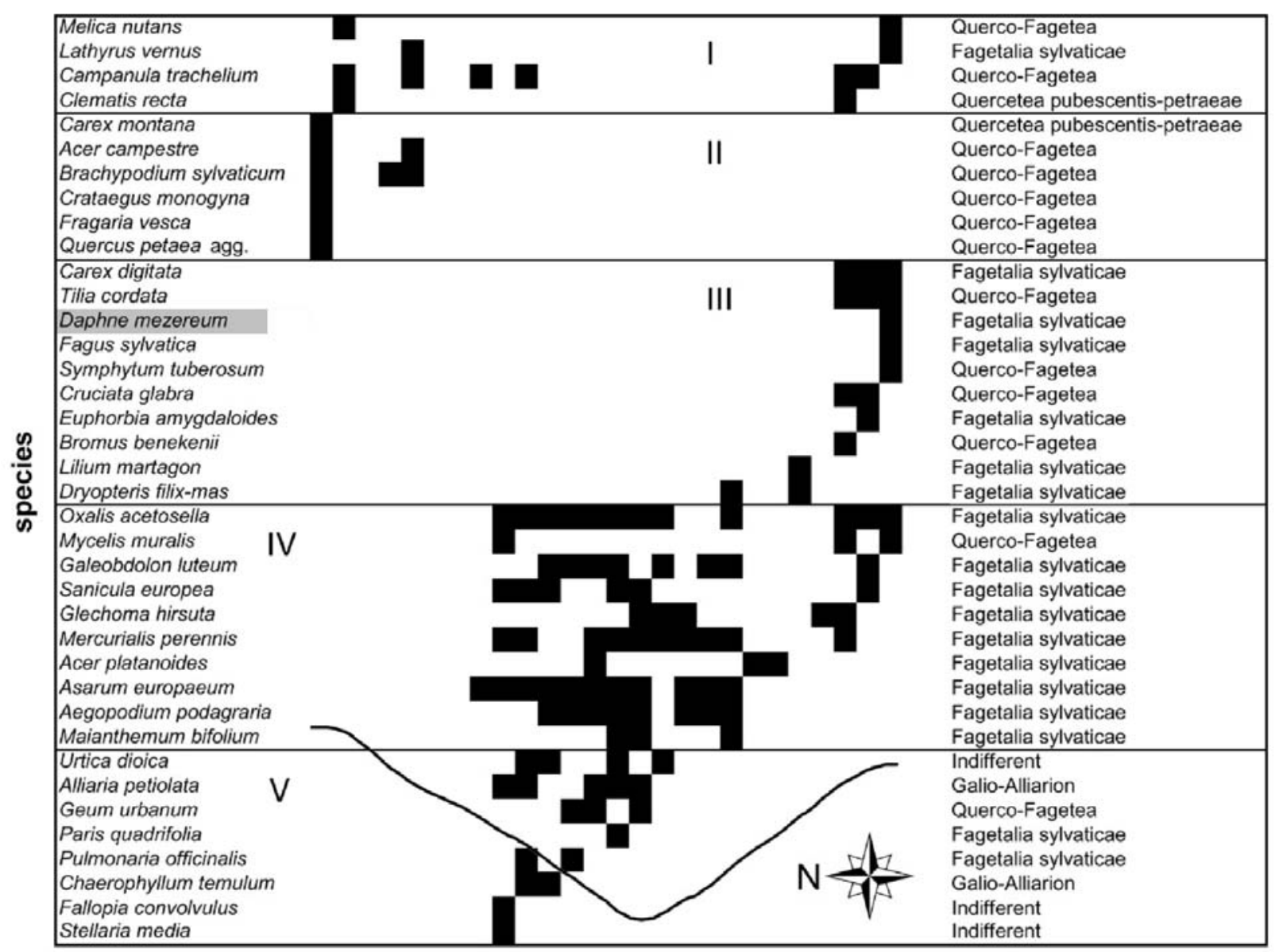

position along the transect

Fig. 5. Species occurrences and relief profile along the transect of doline 3. I - species of the rims and upper slopes; II - species of the south-facing slope; III - species of the north-facing slope; IV - species of the north-facing slope and doline bottom; V - species of the doline bottom. Those species that occur in every part (I-V) of the doline transect include Acer pseudoplatanus, Carpinus betulus, Galium odoratum, Viola reichenbachiana (Fagetalia sylvaticae) and Fraxinus excelsior (Querco-Fagetea). The name of the red-listed plant is grey-shaded.

line were occupied by an oak-hornbeam forest, whereas a ravine forest (Scutellario altissimae-Aceretum) patch occurred in the doline bottom. In doline 2, a semidry grassland (Polygalo majori-Brachypodietum pinnati) covered the rims and slopes, and a montane hay meadow (Anthyllido-Festucetum rubrae) the doline bottom. An oak-hornbeam forest (Carici pilosaeCarpinetum) was located on the upper slopes and rims of doline 3, while a scree forest (Mercuriali-Tilietum) in the doline bottom.

\section{Discussion}

We studied the species composition and vegetation pattern of forested and non-forested solution dolines in Hungary. Our results show that these dolines serve as refuges for many species adapted to very different climatic conditions. In addition, we revealed that vegetation inversion has developed independently of the vegetation cover. However, we found differences in species richness and species turnover, depending on the exposure and vegetation cover. 

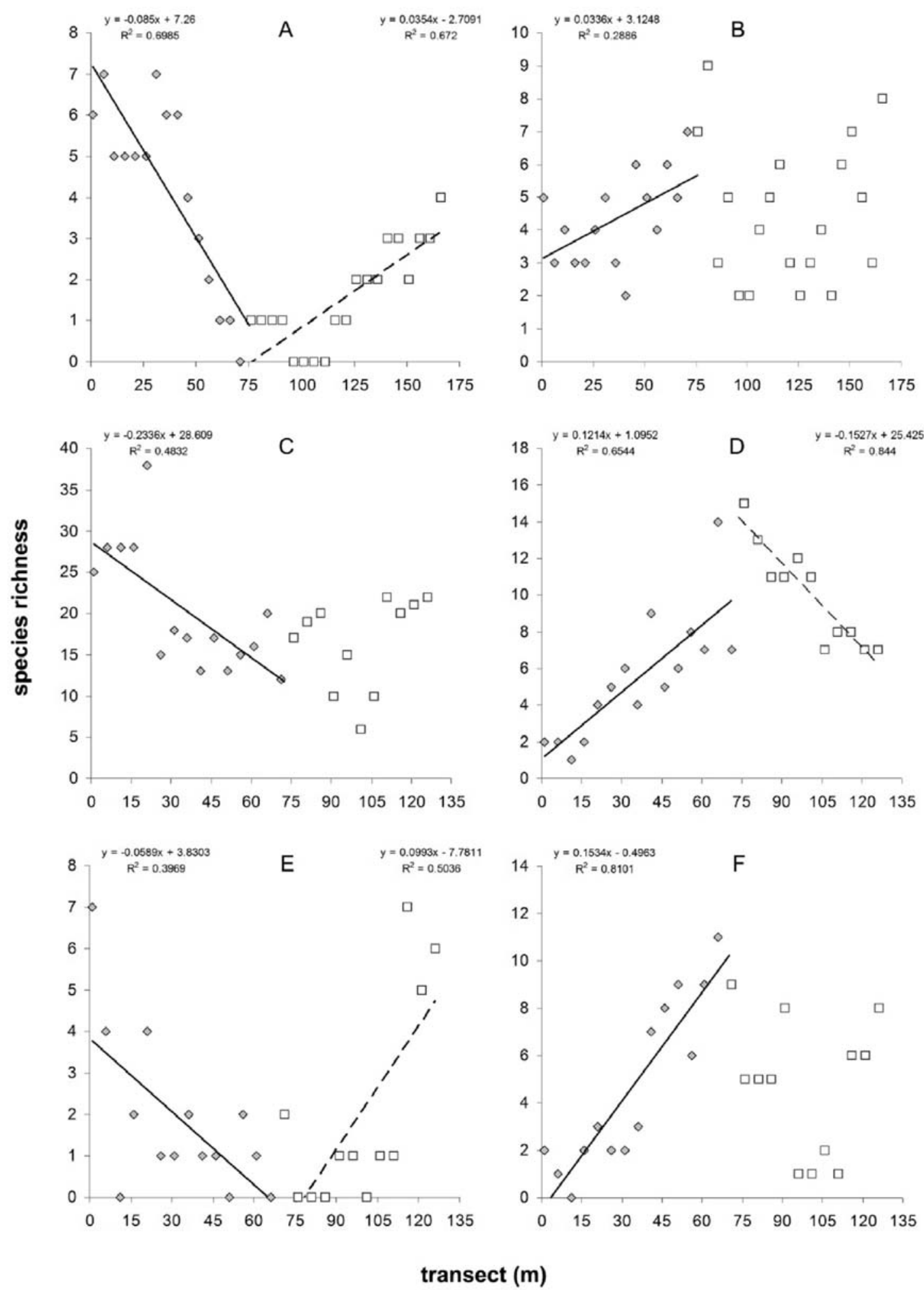

Fig. 6. The relationship between species richness and doline topography (i.e. position along the transect) in solution dolines of Hungary. $\mathrm{A}$ - dry group in doline 1; B - wet group in doline 1; C - dry group in doline 2; D - wet group in doline 2; $\mathrm{E}$ - dry group in doline 3; $\mathrm{F}$ - wet group in doline 3 .

Understanding the patterns of doline vegetation requires an understanding of the spatial and temporal patterns of microclimate (Whiteman et al. 2004; Antonić et al. 2007). The interaction between topography and climate is very complex and its details are not completely understood (Dobrowski 2011). There is no doubt, however, that topography and related terrain effects strongly affect the local climatic conditions (Bátori et al. 2009; Geiger 1950; Whiteman et al. 2004) and therefore the species composition and vegetation 


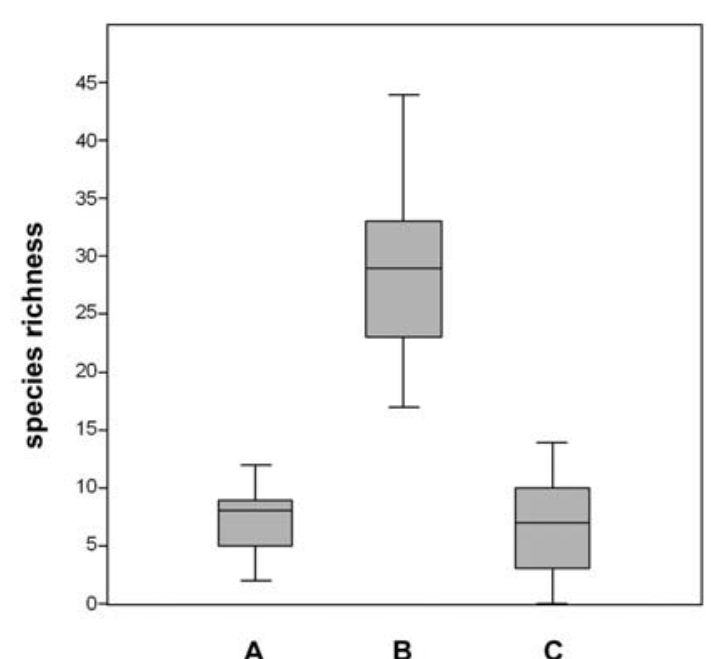

Fig. 7. Species richness of the three dolines studied. A - doline 1; $\mathrm{B}$ - doline 2; $\mathrm{C}$ - doline 3 .

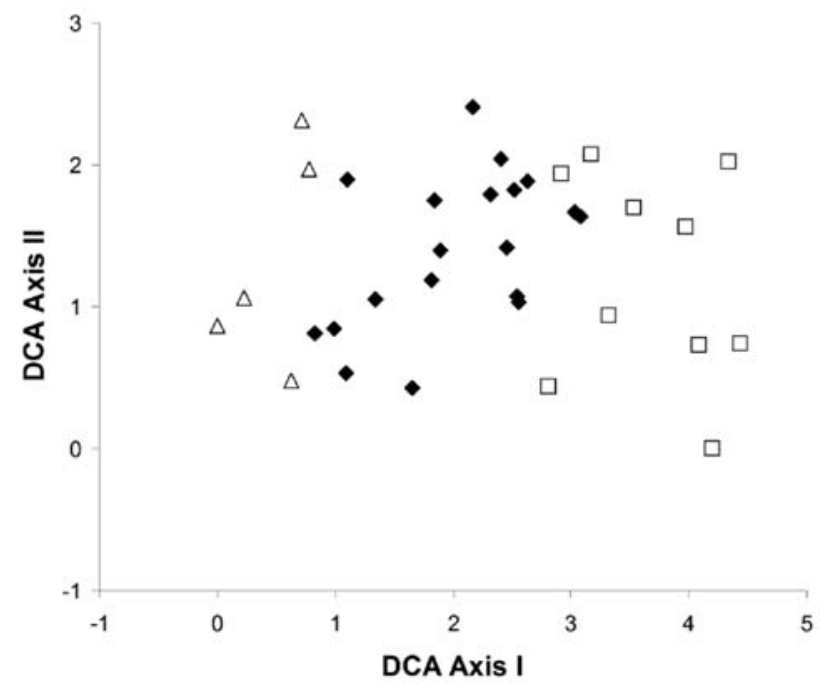

Fig. 8. DCA ordination scattergram of the 34 plots of doline 1 . Eigenvalues of the first two axes were 0.6183 and 0.2392 , respectively. $\Delta$ : transitional forest stand (Potentillo micranthaeQuercetum dalechampii and Asperulo taurinae-Carpinetum); -: Asperulo taurinae-Carpinetum; $\square$ : Scutellario altissimaeAceretum.

pattern. At night, a cold air lake builds up in the dolines, significantly determining the ecological processes on the slopes (Bárány-Kevei 1999). In an early study (Bacsó \& Zólyomi 1934) revealed that the microclimate of dolines covered with grasslands may be very extreme and the average, minimum and maximum temperature values change markedly depending on which doline parts are considered. Similar results are shown by Lehmann (1970), who compared the microclimate of two large dolines, one of which was covered with mesic forests and the other one with a forest clear-cut. The two dolines differed considerably concerning air humidity and temperature regimes (air humidity changed between $95 \%$ and $100 \%$ while the temperature changed between $18^{\circ} \mathrm{C}$ and $25^{\circ} \mathrm{C}$ in the forested doline, while

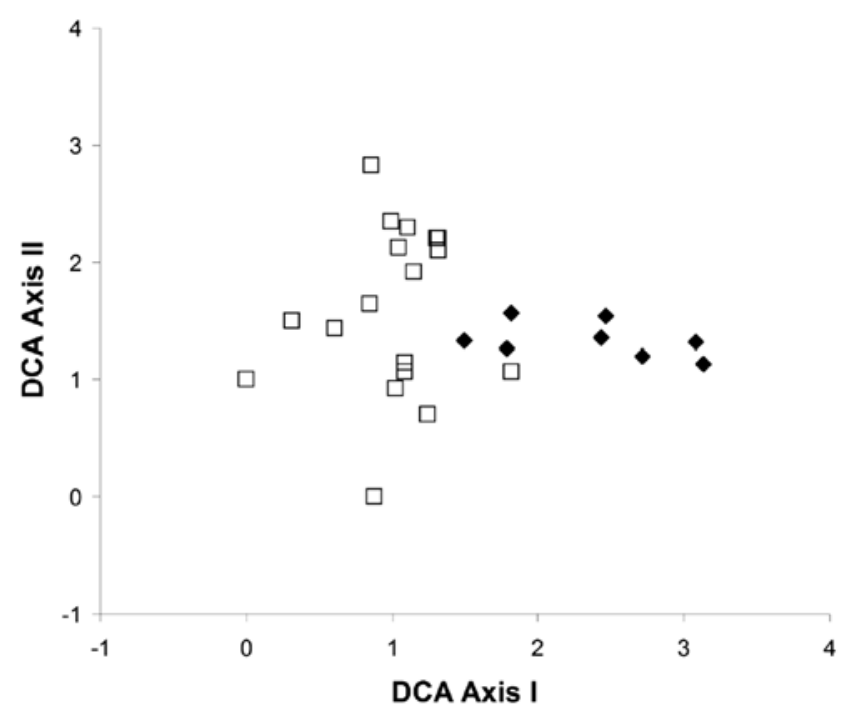

Fig. 9. DCA ordination scattergram of the 26 plots of doline 2. Eigenvalues of the first two axes were 0.4121 and 0.2687 , respectively. : Polygalo majori-Brachypodietum pinnati; $\square$ : Anthyllido-Festucetum rubrae.

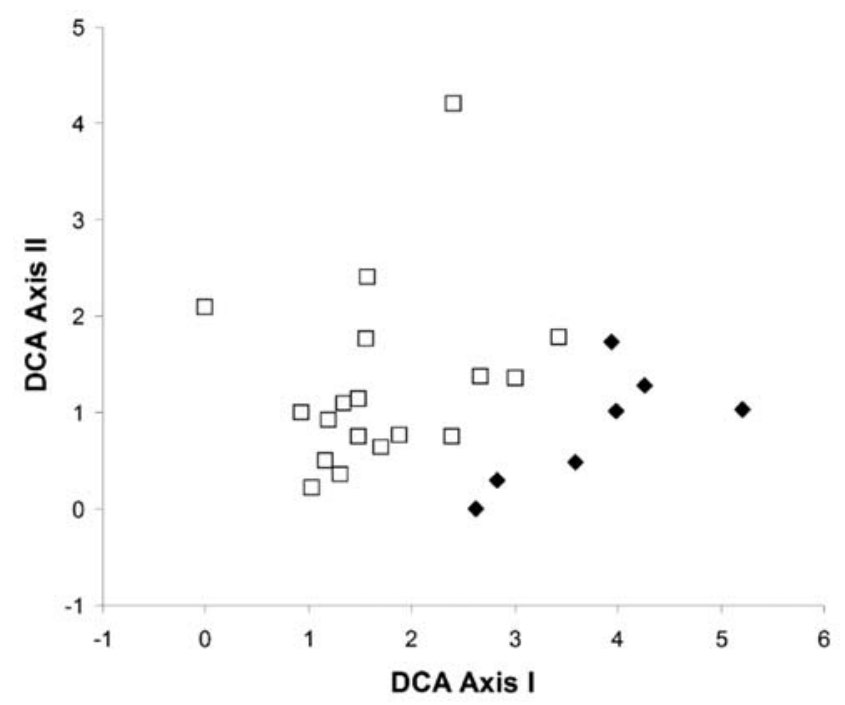

Fig. 10. DCA ordination scattergram of the 26 plots of doline 3. Eigenvalues of the first two axes were 0.6526 and 0.4185 , respectively. : Carici pilosae-Carpinetum; $\square$ : Mercuriali-Tilietum.

these values changed between $50 \%$ and $100 \%$ and $10^{\circ} \mathrm{C}$ and $32^{\circ} \mathrm{C}$ in the clear-cut doline).

Recent studies (Bátori et al. 2011, 2012) discuss the potential role of forested dolines in mitigating species loss under future global warming and conclude that these depressions may play an essential role in reducing extinction rate of plant species, as they did in earlier geological times as well (Horvat 1953). However, species preservation depends on many factors. Bátori et al. (2014a) emphasize that the types of dolines, the steepness of the slopes, the latitude and the vegetation history have a major impact on plant growth and survival. For example, when considering only solution dolines with similar depth/diameter ratio, larger dolines can be considered better refugia for plants than 
smaller ones. Our results revealed that all vegetation types found on the deeper slopes of the dolines and in the doline bottoms contain many plants that usually occur at higher elevations or in otherwise cool and moist habitats. Thus, we can conclude that not only the forested (Bátori et al. 2012, 2014a) but also the nonforested dolines play an important role in the preservation of vascular plant species in Hungary, and this phenomenon is attributed to the presence of specific environmental gradients. Presumably, the high-mountain and relict species of the studied dolines would survive for a long time under climate change.

We also found that variation within the dry and the wet species groups is more pronounced on the southfacing doline slopes. In Hungary, the south-facing slopes receive much more solar radiation than the north-facing ones, therefore the south-facing doline parts are warmer than the opposite ones (Jakucs 1971). Our results are in good agreement with the findings of other authors who found significant differences between the vegetation characteristics of north-facing and south-facing slopes in several environments (Hutchins et al. 1976; Armesto \& Martínez, 1978; Hicks \& Frank 1984; Kutiel \& Lavee 1999; Erdős et al. 2012). The strong increase in species richness within the wet group along the north-facing slope of the non-forested doline can probably be explained by steep nighttime temperature gradients. However, the high number of cool-adapted species on the north-facing slopes of the forested dolines may primarily be related to the mitigating effect of the forest on temperature regime (Bátori et al. 2014b).

In contrast with our expectations, the species turnover is higher in the forested dolines. However, changes of the species richness of the wet group along the transects are pronounced only in the non-forested doline. At least two explanations of this apparent contradiction are possible. Firstly, the forest associations found in both areas (Asperulo taurinae-Carpinetum, Carici pilosae-Carpinetum, Helleboro odori-Fagetum, Mercuriali-Tilietum and Scutellario altissimae-Aceretum) are relatively rich in beech forest species (Fagetalia sylvaticae) (Jakucs \& Jurko 1967; Kevey 1997; Kevey \& Borhidi 1998; Nagy 2004), which have successfully colonized the cool north-facing slopes of the forested dolines as well. However, if we consider only the occurrences of individual species, we can conclude that there is a strong spatial separation between species of Fagetalia sylvaticae along the slopes of the forested dolines (presumably following soil moisture changes), strongly contributing to the high species turnover. For example, Lathyrus vernus occurs on the upper slopes of the dolines but it is absent from the bottoms. Secondly, several historical events (e.g. grazing and mowing regimes) might shape the vegetation pattern along the slopes of the non-forested doline and might contribute to the homogenization of the vegetation (Bárány-Kevei 1998).

Our results suggest that the forest cover exerts a major impact on species richness and species turnover in karst dolines and does not influence the phenomena of species preservation and vegetation inversion. We can conclude that the karst dolines of Hungary can be considered as potential refugia for many vascular plants under future global warming and are thus very valuable from a nature conservation point of view. Future investigations are necessary to develop our understanding of the relationships between vegetation cover and different vegetation characteristics in karst dolines in relation to altitude, regional climate and slope exposure.

\section{Acknowledgements}

This research was supported by the European Union, Hungary, and co-financed by the European Social Fund in the framework of TÁMOP 4.2.4. A/2-11-1-2012-0001 'National Excellence Program'.

\section{References}

Antonić O., Kušan V. \& Hrašovec B. 1997. Microclimatic and topoclimatic differences between the phytocoenoses in the Viljska Ponikva Sinkhole, Mt. Risnjak, Croatia. Hrvatski Meteorološki Časopis 32: 37-49.

Armesto J.J. \& Martínez J.A. 1978. Relations between vegetation structure and slope aspect in the Mediterranean region of Chile. J. Ecol. 66: 881-889.

Bacsó N. \& Zólyomi B. 1934. Mikroklíma és növényzet a Bükkfennsíkon. Időjárás 38: 177-196.

Bárány-Kevei I. 1998. Connection between morphology and ecological factors of karst dolines (Aggtelek Hills, Hungary). Suppl. Geogr. Fis. Dinam. Quat III, T. 4-1998. 115-119.

Bárány-Kevei I.1999. Microclimate of karstic dolines. Acta Climatologica 32-33: 19-27.

Bartha A. 1933. Szakosztály ügyek - Dracocephalum ruyschiana a Bükk hegységben. Bot. Közl. 30: 114.

Bátori Z., Csiky J., Erdős L., Morschhauser T., Török P. \& Körmöczi L. 2009. Vegetation of the dolines in Mecsek Mountains (South Hungary) in relation to the local plant communities. Acta Carsologica 38: 237-252.

Bátori Z., Csiky J., Farkas T., Vojtkó E.A., Erdős L., Kovács D., Wirth T., Körmöczi L. \& Vojtkó A. 2014a. The conservation value of karst dolines for vascular plants in woodland habitats of Hungary: refugia and climate change. Int. J. Speleol. 43: $15-26$.

Bátori Z., Gallé R., Erdős L. \& Körmöczi L. 2011. Ecological conditions, flora and vegetation of a large doline in the Mecsek Mountains (South Hungary). Acta Bot. Croat. 70: 147-155.

Bátori Z., Körmöczi L., Erdős L., Zalatnai M. \& Csiky J. 2012. Importance of karst sinkholes in preserving relict, mountain and wet woodland plant species under sub-Mediterranean climate: a case study from southern Hungary. J. Cave Karst Stud. 74: 127-144.

Bátori Z., Lengyel A., Maróti M., Körmöczi L., Tölgyesi Cs., Bíró A., Tóth M., Kincses Z., Cseh V., Erdős L. 2014b. Microclimate-vegetation relationships in natural habitat islands: species preservation and conservation perspectives. Időjárás 118: 257-281.

Beck v. Mannagetta G. 1906. Die Umkehrung der Pflanzenregionen in den Dolinen des Karstes. Sitzungsberichte der Kaiserliche Akademie der Wissenschaften in Wien 65: 3-4.

Borhidi A., Kevey B. \& Lendvai G. 2012. Plant communities of Hungary. Akadémiai Kiadó, Budapest, 544 pp.

Dakskobler I., Sinjur I., Veber I. \& Zupan B. 2008. Localities and sites of Pulsatilla vernalis in the Julian Alps. Hacquetia 7: 47-69.

Dobrowski S.Z. 2011. A climatic basis for microrefugia: the influence of terrain on climate. Glob. Change Biol. 17: 1022-1035.

Egli B.R. 1991. The special flora, ecological and edaphic conditions of dolines in the mountains of Crete. Botanica Chronica 10: $325-335$. 
Erdős L., Méri Á., Bátori Z., Gallé R. \& Körmöczi L. 2012. Northsouth facing vegetation gradients in the Villány Mts: a case study on the population and the community level. Pakistan J. Bot. 44: 927-932.

Gargano D., Vecchio G. \& Bernardo L. 2010. Plant-soil relationships in fragments of Mediterranean snow-beds: ecological and conservation implications. Plant Ecol. 207: 175-189.

Geiger R., 1950. Das Klima der bodennahen Luftschicht: Ein Lehrbuch der Mikroklimatologie. Die Wissenschaft, 4. Verlag F. Vieweg and Sohn, Braunschweig, 460 pp.

Hammer Ø., Harper D.A.T. \& Ryan P.D. (2001). PAST: Paleontological Statistics Software Package for Education and Data Analysis. Palaeontol Electron, http://palaeo-electronica.org/ 2001_1/past/issue1_01.htm

Hampe A. \& Jump A.S. 2011. Climate relicts: Past, present, future. Annu. Rev. Ecol. Evol. Syst 42: 313-333.

Hicks R.R. \& Frank P.S. 1984. Relationship of aspect to soil nutrients, species importance and biomass in a forested watershed in West Virginia. For. Ecol. Manage. 8: 281-291.

Hill M.O. \& Gauch H.G. 1980. Detrended correspondence analysis: an improved ordination technique. Vegetatio 42: 47-58.

Horvat I. 1953. Vegetacija ponikava. Geografski Glasnik 14-15: $1-5$.

Hutchins R.B., Blevins R.L., Hill J.D. \& White E.H. 1976. The influence of soils and microclimate on vegetation of forested slopes in Eastern Kentucky. Soil Sci. 121: 234-241.

Jakucs L. 1971. A karsztok morfogenetikája. Akadémiai Kiadó, Budapest, 310 pp.

Jakucs P. \& Jurko A. 1967. Querco petraeae-Carpinetum waldsteinietosum, eine neue Subasszoziation aus dem slowakischen und ungarischen Karstgebiet. Biologia 22: 321-335.

Kevey B. 1997. A Nyugati-Mecsek szurdokerdei (Scutellario altissimae-Aceretum (Horvát A. O. 1958) Soó et Borhidi in Soó 1962), pp. 75-79. In: Borhidi A. \& Szabó L.Gy. (eds) Studia Phytologica Jubilaria. Dissertationes in honorem jubilantis Adolf Olivér Horvát Doctor Academiae in annoversario nonagesimo nativitatis 1907-1997, Pécs, Hungary.

Kevey B. \& Borhidi A. 1998. Top-forest (Aconito anthoraeFraxinetum orni). A special ecotonal case in the phytosociological system (Mecsek Mts., South Hungary). Acta Bot. Hung. 41: 27-121.

Király G. (ed.) 2007. Vörös lista. A magyarországi edényes flóra veszélyeztetett fajai. Saját kiadás, Sopron, $73 \mathrm{pp}$.

Király G. (ed.) 2009. Új magyar füvészkönyv. Aggteleki Nemzeti Park Igazgatóság, Jósvafö, 616 pp.
Kutiel P. \& Lavee H. 1999. Effect of slope aspect on soil and vegetation properties along an aridity transect. Isr. J. Plant Sci. 47: 169-178.

Lazarević P., Lazarević M., Krivošej Z. \& Stevanović V. 2009. On the distribution of Dracocephalum ruyschiana (Lamiaceae) in the Balkan Peninsula. Phytologia Balcanica 15: 175-179.

Lehmann A. 1970. Tarvágás által okozott ökológiai változások az abaligeti karszton. Pécsi Müszaki Szemle 25: 15-21.

Marosi S. \& Somogyi S. (eds) 1990. Magyarország kistájainak katasztere I-II. MTA Földrajztudományi Kutató Intézet, Budapest, $479 \mathrm{pp}$.

Nagy J. 2004. Scree forests (Mercuriali-Tilietum) of the Börzsöny Mountains, Hungary. Acta Bot. Hung. 46: 319-336.

Özkan K., Gulsoy S., Mert A., Ozturk M. \& Muys B. 2010. Plant distribution-altitude and landform relationships in karstic sinkholes of Mediterranean region of Turkey. J. Environ. Biol. 31: $51-61$.

R Development Core Team. 2009. R: A Language and Environment for Statistical Computing. R Foundation for Statistical Computing, Vienna. www.R-project.org

Redžić S., Barudanović S., Trakić S. \& Kulijer D. 2011. Vascular plant biodiversity richness and endemo-relictness of the karst mountains Prenj, Čvrsniva and Cabulja in Bosnia and Herzegovina (W. Balkan). Acta Carsologica 40: 527-555.

Ujvárosy A. 1998. Földrajzi helyzet, éghajlati viszonyok, pp. 2226. In: Baross G. (ed.), Az Aggteleki Nemzeti Park. Budapest, Mezőgazda Kiadó, Hungary.

Vilisics F., Sólymos P., Nagy A., Farkas R., Kemencei Z. \& Hornung E. 2011. Small scale gradient effects on isopds (Crustacea: Oniscidea) in karstic sinkholes. Biologia 66: 499-505.

Vojtkó A.1994. Adatok a Bükk hegység flórájához. Bot. Közl. 81: $165-175$.

Vojtkó A.2003. A Tornai-karszt töbreinek cönológiai jellegzetességei. Bot. Közl. 90: 167-168.

Webster R. 1978. Optimally partitioning soil transects. J. Soil Sci. 29: 388-402.

Whiteman C.D., Haiden T., Pospichal B., Eisenbach S. \& Steinacker R. 2004. Minimum temperatures, diurnal temperature ranges, and temperature inversion in limestone sinkholes of different sizes and shapes. J. Appl. Meteorol. 43: 1224-1236.

Yannitsaros A.G., Constantinidis T.A. \& Vassiliades D.D.1996. The rediscovery of Biebersteinia orphanidis Boiss. (Geraniaceae) in Greece. Bot. J. Linn. Soc. 120: 239-242.

Received November 27, 2013 Accepted June 27, 2014 